\title{
Multi-Sensory Informatics Education
}

\author{
Zoltan KATAI ${ }^{1}$, Laszlo TOTH ${ }^{2}$, Alpar Karoly ADORJANI ${ }^{3}$ \\ ${ }^{1}$ Sapientia University, Department of Mathematics and Informatics \\ 540485, Tirgu Mures, Op. 9, Cp. 4, Romania \\ ${ }^{2}$ S.C. Neogen S.A. \\ Tirgu Mures, Str. Mihai Eminescu 48, Romania \\ ${ }^{3}$ S.C. INTER SOFT S.R.L. \\ Tirgu Mures, Str. Cutezantei 57, Romania \\ e-mail:katai_zoltan@ms.sapientia.ro,lacixp@yahoo.com,adorjanialpar@yahoo.com
}

Received: November 2013

\begin{abstract}
A recent report by the joint Informatics Europe \& ACM Europe Working Group on Informatics Education emphasizes that: (1) computational thinking is an important ability that all people should possess; (2) informatics-based concepts, abilities and skills are teachable, and must be included in the primary and particularly in the secondary school curriculum. Accordingly, the "2013 Best Practices in Education Award" (organized by Informatics Europe) was devoted to initiatives promoting Informatics Education in Primary and Secondary Schools. In this paper we present one of the winning projects: "Multi-Sensory Informatics Education". We have developed effective multi-sensory methods and software-tools to improve the teaching-learning process of elementary, sorting and recursive algorithms. The technologically and artistically enhanced learning environment we present has also the potential to promote intercultural computer science education and the algorithmic thinking of both science- and humanities-oriented learners.
\end{abstract}

Keywords: multisensory education, informatics education, intercultural education, algorithmic thinking.

\section{Introduction}

According to a recent report of the joint Informatics Europe \& ACM Europe Working Group on Informatics Education (IE \& ACM, 2013), for a nation or group of nations to compete in the race for technological innovation, the general population must understand the basics of informatics: the science behind Information Technology. To be competitive in the 21 st century's job market, students must understand the key concepts of informatics. The report describes computational thinking as an important ability that all people should possess. The working group emphasizes that informatics-based concepts, abilities and skills are teachable, and must be included in the primary and particularly in the secondary school curriculum. 
Accordingly, the "2013 Best Practices in Education Award" (organized by Informatics Europe) was devoted to initiatives promoting Informatics Education in Primary and Secondary Schools. The winners were presented in a special ceremony held during the ECSS 2013 in Amsterdam, The Netherlands. Two teams from Eastern/Central Europe (Romania: Sapientia University; Poland: Warsaw School of Computer Science) shared this year's award.

The official website of Informatics Europe states: "The evaluation committee praised the originality of the proposal by Zoltan Katai, Laszlo Toth and Alpar Karoly Adorjani: Multi-Sensory Informatics Education. Mixing algorithms learning with sensory experience is a very innovative teaching experiment. The key concept of this proposal is Computer Science education for all, using a creative approach. The committee was impressed and appreciated this approach of abstracting away almost all details that might hinder understanding the idea or principle of an algorithm or a paradigm. The enactments thus not only can be used flexibly in teaching environments irrespective of a particular programming- or spoken-language but can be used as a starting point for the teacher to drill down into more technical concepts. Another particularity of the project is its intercultural character - sorting algorithms illustrated by Central European folk dancing" (Informatics Europe, 2013). In the following we present our Multi-Sensory Informatics Education project.

\section{Multi-Sensory Informatics Education}

In the last seven years we have developed multi-sensory methods (Katai et al., 2008; Katai, 2009; Katai and Toth, 2010; Katai, 2013) for the teaching-learning of some basic concepts that may be included in every introductory informatics course: algorithms; programming languages; abstraction; structured programming (sequence, selection, repetition); basic data structures; basic algorithms (searching, sorting, etc); recursivity; performance and complexity; parallelism, etc. More senses mean more efficient teachinglearning processes because:

- More senses - more information.

- Different students - different dominant senses.

- Different students - different "intelligences".

- Multiple-senses - more pathways of locating the stored information.

- Multiple-senses - distributed loading.

- Combined senses - more efficient learning process.

\subsection{Multisensory Education in the Digital Era}

Montessori initiated the multi-sensory learning movement about 90 years ago. In recent decades technology integration in education has opened up new vistas for researchers and teachers who are interested in multi-sensory teaching-learning methods. Reflecting 
on terms like multi-media and multi-sensory we understand that the nearly one hundred year old multi-sensory movement has entered a new dynamic era.

Revolutionary discoveries in neuroscience and important developments in cognitive psychology have resulted in new ways of thinking about the relationship between the senses and learning. It is more and more evident that our brain is organized to elaborate information coming from the different sensory channels, cooperatively, in order to create a complete vision of reality (Voto et al., 2005). Some research (Shaywitz, 2003) addresses multi-sensory learning neurons, specific neurons in the brain that fire only when more than one sensory modality is activated by the environment (Kavenaugh, 1991). According to Hung (2003) the recent findings in neuroscience have immediate implications for higher-level thinking skills (abstract problem solving, inference, deduction and so on). As Stevens and Goldberg (2001) state, two of the core principles of brain-based learning are: multi-sensory input is desired by our brains; and, learning engages the whole body. Researchers emphasise that senses reach not only our feelings, emotions and aesthetic perception, but our intellect as well. In the opinion of the medical neuroscientist Dave Warner, the traditional forms of information representation have been "perceptually deficient", meaning that even multimedia digital content fails to consider "the extraordinary capacity of our brain to capture and process information from [all of] our senses" (Staley, 2006).

\subsection{Increasing Student Motivation: a Major Issue for Modern Education}

According to Prensky (2001) "today's students are no longer the people our educational system was designed to teach". They should be approached as "digital natives" being more familiar and comfortable with the use of technology than with traditional lecturing methods (Prensky, 2007; Spires et al., 2008). Otta and Tavela (2010) emphasise that "new millennium learners" (Pedró, 2006) are not indifferent to the quality of the e-learning experience. The instructional challenge of the self-paced e-learning environment lies in keeping students enthusiastic, focused, and engaged (generating, sustaining, not diminishing) by optimally exploring the potential which lies in technology.

Constructivist theory describes motivation as a "necessary prerequisite and co-requisite for learning" (Palmer, 2005). Motivation is required to initiate and to catalyse the learning process until the knowledge construction has been completed (Pintrich, 1993). Motivation theorists distinguish between intrinsic motivation (referring to internal drive; doing something because it is inherently interesting or enjoyable) and extrinsic motivation (coming from factors outside the individual; doing something because it leads to a separable outcome) (Deci and Ryan, 1985). Research on intrinsic motivation has revealed the outstanding role this type of motivation plays in promoting high-quality learning (Fair and Silvestri, 1992; Martens et al., 2004). It has been proven that environments which engage students in the learning process yield stronger intrinsic motivation (Lepper et al., 2005; Robertson and Howells, 2008).

Stimulating motivation is a primary goal regarding the introductory part of any elearning or traditional lesson. Stimulating curiosity can be an efficient strategy in this 
sense. Curiosity is an emotional-motivational state that has a high potential to make learning intrinsically rewarding and highly pleasurable (Day, 1971; Kashdan et al., 2004). Providing novelty, incongruity and surprise are considered effective ways to arouse curiosity and to combat apathy (Berlyne, 1960; Keller, 1983).

Active involvement and moderate-progressive challenge should play key roles in sustaining students' motivation during the body of the learning unit. Research on challenge as a motivator shows that moderate challenges (a balance of challenge and skills) are optimally motivating (Nakamura and Csikszentmihalyi, 2002; Turner and Meyer, 2004; Otta and Tavella, 2010). Relevant active involvement is crucial regarding intrinsic motivation, since it may have a determinative influence on sustaining and maintaining students' engagement during the learning process (Lepper and Malone, 1987; Garris et al., 2002).

The didactical methods we present below aim to exploit the following motivational principles:

- Purposeful focus on arousing and sustaining students' motivation.

- Principle of genuine active involvement.

- Principle of moderate progressive challenge.

- Principle of gradual shift from concrete to abstract.

\subsection{Technologically Enhanced Multi-Sensory Method for Teaching-Learning Elementary Algorithms}

In (Katai et al., 2008) we introduced a new multi-sensory method to improve the teaching-learning of elementary algorithms. Any elementary algorithm has a "loop skeleton", its structure of loops. Instructions representing the nucleus of the loops can be seen as the "meat-parts" of the algorithm. We recommended the following two-step method: (1) the loop skeleton is established, and (2) the skeleton is filled up with adequate instructions. We have also developed a software-tool that makes it possible to create program-skeletons with different loop structures in an automatic way: (1) giving the parameters of the loop skeleton; (2) drumming the loop skeleton in, (having the keyboard students drum the rhythm-pattern of certain loop skeletons). Furthermore, the software plants piano sound and delay procedures in the nuclei of each loop instruction. This module functions as a loudspeaker for the loop skeletons. For algorithms having loops in both branches of a selection, we implemented the same sounds, but with different musical instruments. The application makes possible the following multi-sensory learning experience: While students are listening to the loop skeleton of the algorithm (represented by its pianosound sequence), they keep their eyes on the running program (the instruction which is being executed is highlighted). In this way they can see, hear and feel the pulsation of the algorithms.

In order to investigate the efficiency of the presented method and software-tool we performed a didactical experiment. The results confirmed our theoretical expectations that the multi-sensory method we developed contributes to the effectiveness of the learning process and of memorising. (For more details see Katai et al., 2008). 


\subsection{Technologically Enhanced Multi-Sensory Method for Teaching-Learning Recursion}

In (Katai, 2009) we introduced a new multi-sensory method to improve the teachinglearning of recursive algorithms. The method explores, in a harmonic way, the visual, auditory and kinaesthetic senses of students, helping them to imagine abstract concepts and processes. Students are invited to play so called "recursive scenarios" (see Fig. 1). The method also makes use of didactical software that creates "the melody line" of the recursive procedures and functions.

In order to prove empirically the efficiency of the method, we performed an experiment too. The results support the conclusion that the multi-sensory method we propose improves students' skill in analysing, designing and implementing recursive procedures and functions. (For more details see Katai, 2009).

\subsection{Technologically and Artistically Enhanced Multi-Sensory Method for the Teaching-Learning of Sorting Algorithms}

Two main reasons why science and art represent a winning combination in educational contexts are:
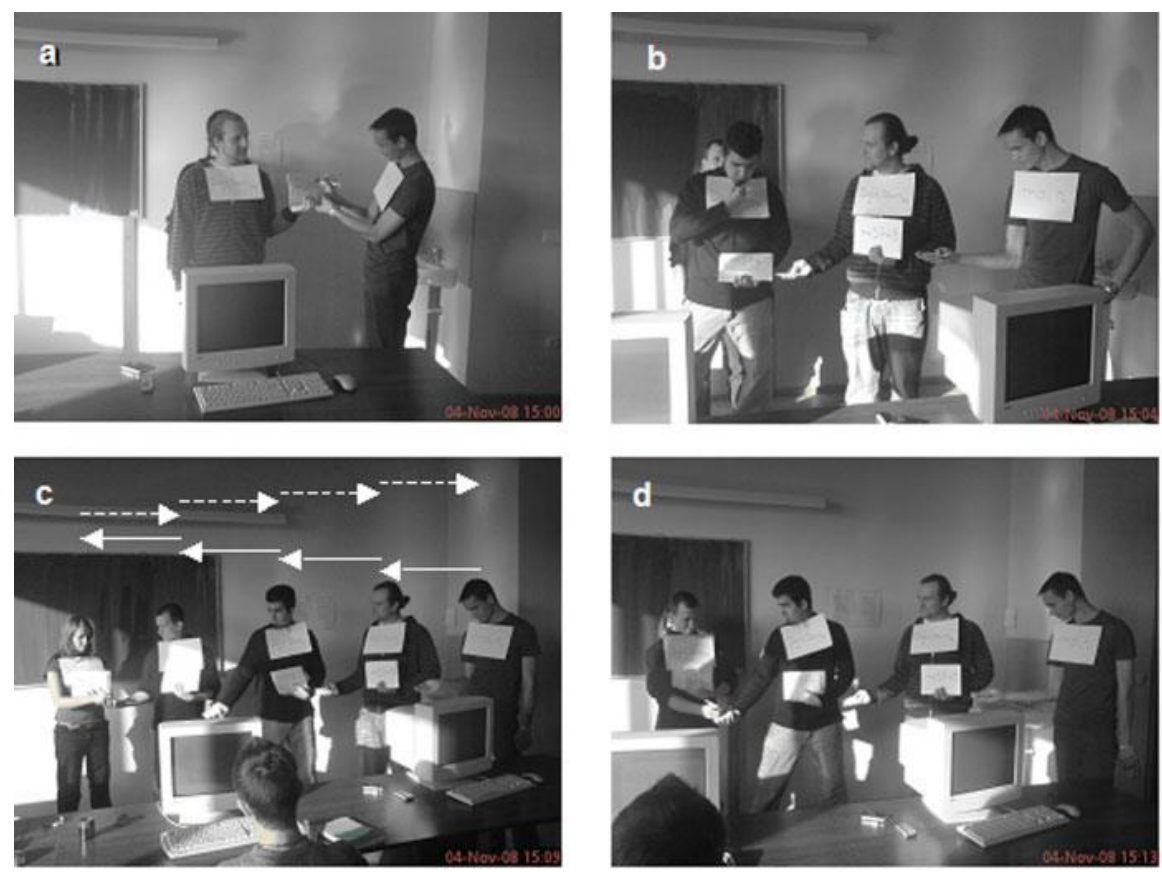

Fig. 1. Staging a recursive scene. 
(1) Experiments applying neuroimaging technologies (MEG, FMRI, PET, etc.) have shown that activities involving numbers, logic, sequential tasks and general analysis are more closely associated with the left side of the brain. Then again, activities involving music, imagination, colours, or creative expression are more active in the right hemisphere. Some research in this field has revealed that a balanced involvement of both sides of the brain in the classroom could significantly improve the teaching-learning process (Eisenhower SCIMAST, 1997).

(2) Gardner $(1993,2000)$ has revealed that a mixture of different ways of learning characterises us, and he identified nine intelligences (musical intelligence, bodilykinaesthetic intelligence, logical-mathematical intelligence, etc.). One of the important messages of Gardner's work is that students need to learn in various ways. For example, teachers should not allow their visual or logical learners to rely only on their most comfortable intelligence.

In (Katai and Toth, 2010) we focused on how dance can be involved in informatics education (sorting algorithms). The method takes additional multi-sensory elements into the programming-education through arts (dance, music, rhythm, theatrical role-playing). Combining these art forms teachers could create a multi-sensory learning environment that involves almost all the senses: visual, auditory, kinaesthetic and tactile. We invited students who like dancing to collaborate on our project. Each played the roles of the numbers from a sequence to be sorted, each of them wearing the corresponding number on their clothes. The accompanying music pieces were composed on the basis of Michael Flatley's music. Consulting with the eurhythmics teacher of the faculty we chose real dance-steps for comparing and swapping operations. Once these dance-performances were videotaped we added further graphical elements to the records in order to emphasize that the dancer-numbers are stored in an array, and to highlight the dancer-pair in the focus (see Fig. 2.).

Research results described in (Katai and Toth, 2010) support our conclusion that the presented method and multimedia software-tool may improve informatics education and bring teachers/students closer to Comenius's dream: that teaching and learning should be entirely practical, entirely pleasurable, and such as to make school a real game, i.e. a pleasant prelude to our whole lives (Dobbie, 1986).

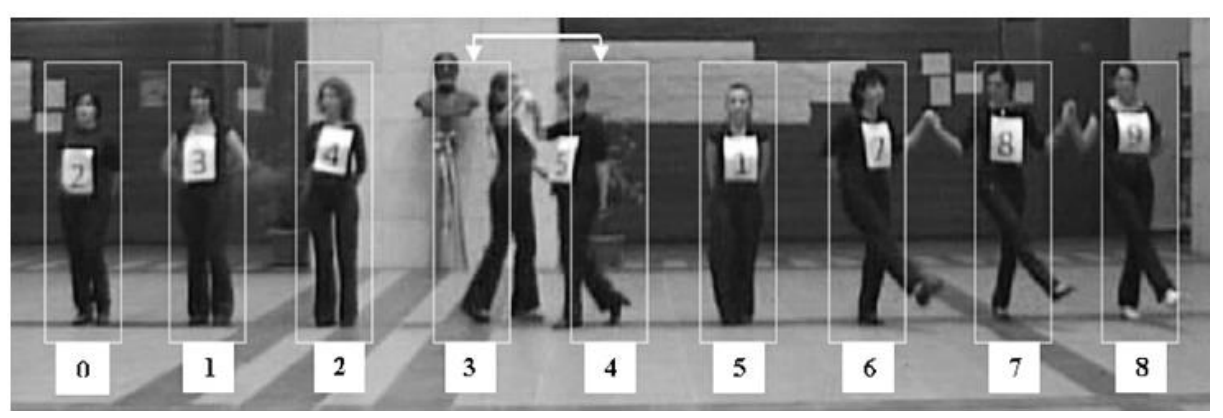

Fig. 2. Bubble-sort dance-performance. 


\subsection{Multi- and Inter-Cultural Informatics Education}

Education shall promote understanding, tolerance and friendship among nations and ethnic groups, and all forms of artistic expression are tools in intercultural education. Effective multicultural education means that cultural pluralism permeates all dimensions (including the curriculums in all subjects at all levels) of the educational process. This is an especially challenging issue for science educators. In (Katai, 2014a) we particularly focused on multicultural content integration in informatics education, through art-based pedagogical tools. We initiated collaboration with a professional art institution, and utilised Romanian, Hungarian, German and Gipsy folk-dance choreographies (to illustrate the cultural diversity in Transylvania, Romania) in order to illustrate different sorting algorithms. The fruits of this collaboration are art-science productions that equally promote multiculturalism and informatics education. In order to test the potential that "algorithmic dances" have for promoting intercultural informatics education, we posted them on the YouTube website. Users' reactions confirmed our expectations.

(http://www.youtube.com/algorythmics)

\subsection{Promoting Algorithmic Thinking in All Students}

Some authors speak about science-oriented and humanities-oriented learners according to their different ways of viewing the world and their different approaches to problemsolving. These and other findings suggest that whereas algorithmic thinking is important for all students, it could be less familiar to humanities-oriented learners than to their science-oriented colleagues.

Algorithmic thinking is a specialised problem-solving competence utilizing several abilities, and is influenced by many other human cognitive factors such as abstract and logical thinking, thinking in structures, creativity etc. (Futschek, 2006). Computer algorithms incorporate several invisible factors and abstractions, and students usually have no real-life references regarding them (Ramadhan, 2000). Additionally, computer programming frequently involves sequential algorithms designed for machines, based on a limited set of elementary instructions. For humans it is natural to cooperate, to act in parallel and to process a large set of high level instructions (Futschek and Moschitz, 2010). All of these factors make algorithmic thinking hard to develop and incorporate into the requirement for good didactical approaches.

In (Katai, 2014b) we presented experimental results revealing that properly calibrated learning tools can effectively promote the algorithmic thinking of both science-oriented and humanities-oriented students. The e-learning environment we developed had been designed to introduce students to the mini-world of sorting algorithms (bubble-sort, insertion-sort, selection-sort, shell-sort, quick-sort and merge-sort). The software tool generates a five-phase learning experience: the algorithm is visualised by a videotaped "sequence of folk dancers" wearing the numbers to be sorted on their clothes (1); the algorithm is animated on a white-box array (storing the number-sequence) (2); followed by 
student reconstructed (3) and orchestrated (4) animations; students are then invited to orchestrate the studied sorting algorithm on a black-box array (being informed about the results of the comparison operations) (5). The application provides an excellent opportunity for a gentle introduction to several algorithm related concepts (best, worst and average case, algorithm complexity, etc). (http: / / www - youtube.com/algorythmics)

We have proposed to implement the following motivational strategy: During the "dance-performance phase" (1) the focus is on arousing curiosity by combining science with art and modern with traditional. The role of the "animation phase" (2) is to help students focus on the key elements of the algorithm and to prepare them for the "doing phases". During the "doing phases" of the e-learning session students are invited to actively participate in the animations according to the principle of moderate-progressive challenge. According to the constructivist learning theory, applying the knowledge they have just gained may result in more effective learning. The tasks of "doing phases" were to:

(3) reconstruct the operation (compare, swap) sequence of the observed animation.

(4) orchestrate the studied sorting algorithm on randomly generated input sequences stored in white-box arrays.

(5) orchestrate the algorithm on sequences stored in black-box arrays.

\section{Evidence of Impact}

Our work culminated in the AlgoRythmics project, consisting of six "sorting-dances" and an online e-learning tool which effectively exploit the didactical value of these dancechoreographies. We have made these didactical tools available and present the feedback we received from the international teaching and learning community in the following:

- YouTube channel: AlgoRythmics.

https://www • youtube.com/user/AlgoRythmics

○ 1,792,999 VIEWs, 12,745 LIKEs and 4,852 SHAREs from 200 countries.

\begin{tabular}{lrrr}
\hline Video & Views & $\begin{array}{l}\text { Estimated Likes } \\
\text { minutes } \\
\text { watched }\end{array}$ & \\
\hline Bubble-sort with Hungarian (“Csángó”) folk dance & 588,067 & 222,580 & 3,439 \\
Quick-sort with Hungarian (Küküllőmenti legényes) folk dance & 430,008 & 413,271 & 4,643 \\
Shell-sort with Hungarian (Székely) folk dance & 260,651 & 80,906 & 1,622 \\
Insert-sort with Romanian folk dance & 210,312 & 96,172 & 1,389 \\
Select-sort with Gypsy folk dance & 181,443 & 102,023 & 809 \\
Merge-sort with Transylvanian-saxon (German) folk dance & 123,848 & 102,630 & 843 \\
\hline
\end{tabular}

- 26 embedded player on other websites.

edx.org, scienceblogs.de, i-programmer.info, etc

- 549,204 VIEWs and 212,066 estimated minutes watched. 
- Facebook page: AlgoRythmics.

https://www. facebook. com/AlgoRythmics

○ 2,828 LIKEs from 20 countries.

- AlgoRythmics website.

http: / / algo-rythmics.ms.sapientia.ro/

○ 2237 visits in 2,5 months.

○ 1740 unique visitors, $22 \%$ returning visitors.

\subsection{Users' Appreciations}

Extracts from users' comments: YouTube, Facebook:

- The words awesome, great, best, nice, brilliant, love, epic, cool, amazing, excellent have appeared more than 200 times in users' comments.

○ 4403 users marked the AlgoRythmics channel as favourite.

- Selected extracts from users' comments:

- Best channel ever!

- Best demonstration on the web!

- Thank you for this initiative. This is the greatest piece of art I have ever seen!

$\circ$ Entertaining and educational at the same time... also I find it incredibly amusing that the 'pointers' are the hats.

- Aha! That would be awesome!!!! BEST IDEA EVER.

- This is the coolest implementation of Quick-sort I've ever seen!

- I will never look at a program the same way again.

- You don't know anything about basic programming until you've seen this.

○ Beautiful piece of art to explain computer science, this is so EPIC! Thanks!

- Amazing way to demonstrate the algorithm. Congratulations (many applauses)!

○ Wow! This combines two of my interests in a way I never expected. Lovely!

$\circ$ Art + Science $=$ Intelligent entertainment.

○ The only true international language!!

○ I'm addicted to this video!

\subsection{Teachers Considering Algorythmics Channel to be Useful}

Extracts from users' comments: YouTube, Facebook.

- I really love your work since I'm working with my university to a similar project called Algomotricity.

- I'm a computer science teacher and think that's brilliant! I think I'll give it a try next time I need to teach sort algorithms!

- Boston College CS102 sent me here.

- Awesome. Every computing student and teacher should watch this.

- This is a great way for a beginning CS student to get an intuitive understanding of how quick-sort works. Highly recommended! 
- Inspire pour les course!!

- Oh my god! This is so brilliant! Do you have a downloable version? I'm gonna show this to my students, but internet is not so fancy around here.

- Awesome! I cannot wait to use with my students. I believe it is a great way to learn sorting algorithms. I became a fan of yours.

- Wunderbar! This is science that's joy! I posed the exercise to my students to extract the partitioning algorithm out of the quicksort dance.

- Pushing to have these videos shown in my University's computer science classes.

- Great way to visualize sorting algorithms and useful as an alternative to reading or classroom teaching!

- Awesome!!! I'm programmer and folklore dancer ... and that's what I call interactive learning ... great idea!

\subsection{Students Considering Algorythmics Channel to be Useful}

Extracts from users' comments: YouTube, Facebook.

- It was so hard to learn it only with math and theories. So easy with these videos! Wonderful! Super mega nice work!

- You're awesome! I love it and my professor loves it too!

- Great work! I now understand quick sort. Thanks!

- Epic, I totally understand it now!

- Estos videos son geniales, me salvaron en un examen de programación!

- Never thought that this algorithm is understandable!

- ....... think I actually understand...

- Man this video helped me more than my teachers ...!!!

- Finally understand the quick-sort method.

- HALLO an meinen Informatik-Grundkurs in Kreuznach!

- I wish my professor were this entertaining.

- This is how our algorithm and data-structure lectures should go like!

- Haha! 30 years after starting university as an IT student I finally understood quicksort. Great visualization!

- Awesome!!! Before I watched this video I didn’t understand this algorithm!

- This is perfect revision as I have my A level computing exam on Thursday.

- We watched this in computer science in school and our teacher said he found this video randomly in the internet.

- This has got to be the greatest math's lesson I've ever had!

- My final exam on trees, graphs, hash tables and all these sort algorithms is Monday, watching these kind of videos is funny and more interesting then my crappy notebook!

- I saw this in my AP computer science class a couple days ago, and now I'm hooked on this song. 
- Finally someone explains it in such a way I can understand!

- We are watching select-sort right now in class. Awesome!

- Brilliant! The bubble sort dance illustrates the concept so well that our teacher shows it in class!

- If my professors did this diddy for class I would not only be amused but I'll never forget. New teaching technique? I sure hope so!

- You can visually see the Algorithm in execution. Great!

- When I have to explain quick sort in my oral exam I may just dance ...

\subsection{Extracts from Online Articles that Appreciated Algorythmics Channel}

- http://www.i-programmer.info

○ You may well have seen many simulations of sorting algorithms that aim to show in novel ways how the algorithm works or perhaps doesn't work quite as well as it should. However I guarantee that you have never seen anything quite in the same league as the videos made by Sapientia University - they are simply crazy but in the nicest possible way. ...

- If you have been following the surreal interpretations of sorting algorithms as folk dances here is the ingenious culmination - the Quicksort, the most difficult of algorithms, complete with hats as pointers. Yes I know I claimed that it would be impossible, or if possible the result would be a modern dance the like of which we have not seen, but... they have done it. The slightly insane dance group at Sapientia University has put together a Hungarian folk dance with steps that follow the Quicksort algorithm. It is worth noting that it takes just short of 7 minutes to sort just ten dancers which really isn't very quick; that only males take part which proves that it is a very dangerous algorithm and, oh yes, two hats are used to mark the progress of the scan! Clever stuff! Now see if you are anywhere near as clever by verifying that they are in fact dancing the Quicksort. If you need help then all I can suggest is that you keep your eye on the hats, notice exactly what happens when they meet and pay attention to the partitions that are produced. The sort of the dance has now reached Merge Sort and it's very tricky - how does it end up with the boy-girl pairing? ...

- http: //www.dyxuchen.com

- The next time you're having trouble in computer science classes grasping the nature of shell sorts and bubble sorts, head over to the AlgoRythmics YouTube channel. There, a group of folk dancers are using Hungarian and Gypsy folk dance to teach people exactly how those sorting operations work, complete with graphic overlays and numbers on their chest and back to show you how the sort functions. ... The whole affair is part of Sapientia University's Intercultural Computer Science Education program. If you understand the sort- 
ing algorithms that are on display, you'll really appreciate them. If you don't understand them but need to learn, you'll like them a lot. If you have no idea what's going on, at least you'll enjoy the dancing.

- http://mrhodotnet.blogspot.com

- Absolutely brilliant series of videos interpreting the various sorting algorithms using folk dance. Nice touch on the conventions for comparisons. The videos have no voice-over or distracting subtitles and are slow enough that you can show the video and comment on each of the steps in the algorithm while it is occurring. After a few steps, have students predict what will happen next (e.g. who will dance next and who will swap places).

- http://antoniofarinha.com

- Computer-related algorithms can be quite hard to understand, and in some cases a simple visual demonstration makes it so much easier. The IT people in the audience might have seen a few of them, but I'm pretty sure none was quite as peculiar as this. AlgoRythmics, a folk-dancing group from Romania's Sapientia University, decided to show how data sorting algorithms work by showing them as dances. Bizarre, right? But strangely mesmerizing, and it sure does the trick of explaining how they work. Until now they did insert-sort, bubble-sort, select-sort and shell-sort. I hear that merge-sort and quick-sort are coming soon.

\section{Conclusions and Future Plans}

Algorithmic thinking and especially computational thinking have become increasingly important abilities in our modern society, abilities that all people should possess. Informatics education in primary and secondary schools can contribute to this goal, but teaching computer algorithms for pupils and particularly for all high school students is quite a challenging task. According to our experience and research results, multisensory informatics education could be a viable solution in this regard.

The more senses involved - the more effective the learning. Recent discoveries, especially in neuroscience and cognitive psychology, have confirmed the validity of this ancient wisdom. Although the term Multi-media and Multi-sensory resonate quite well, multimedia learning materials often fail to sufficiently exploit the extraordinary capacity of our brain to capture and process information from all of our senses. The methods and software-tools we have developed make possible the following multisensory learning experiences:

- Students are invited to drum the loop-structure of the algorithm (using the keyboard of the computer).

- Students are listening to the loop structure of previously coded algorithms (as piano-sound sequences). 
- Students are invited to stage recursive scenarios.

- Students are dancing the studied sorting algorithms.

As a kind of apogee of our project we have elaborated six folk-dance choreographies illustrating six basic sorting algorithms. This collection of algorithmic-dance choreographies also illustrates how the concept of 'unity-in-diversity' can be implemented in an educational context: multicultural artistic performances promote the cause of universal science.

Between watching the dance-performance and coding the algorithm there remains quite a large gap. To narrow this gap, we have developed an online learning environment that invites students to reconstruct/orchestrate the algorithm on randomly generated number sequences stored in white/black arrays. Additionally, we plan to develop another software unit that supports students in coding the sorting strategy they have just learned (see Fig. 3).

Among our further plans are the following:

- To create the "heap-sort dance" and the parallel versions of quick- and merge-sort dances.

- To incorporate all the software tools we have developed in a single online learning environment.

- To develop a one semester curriculum to promote algorithmic thinking in all students at all levels.

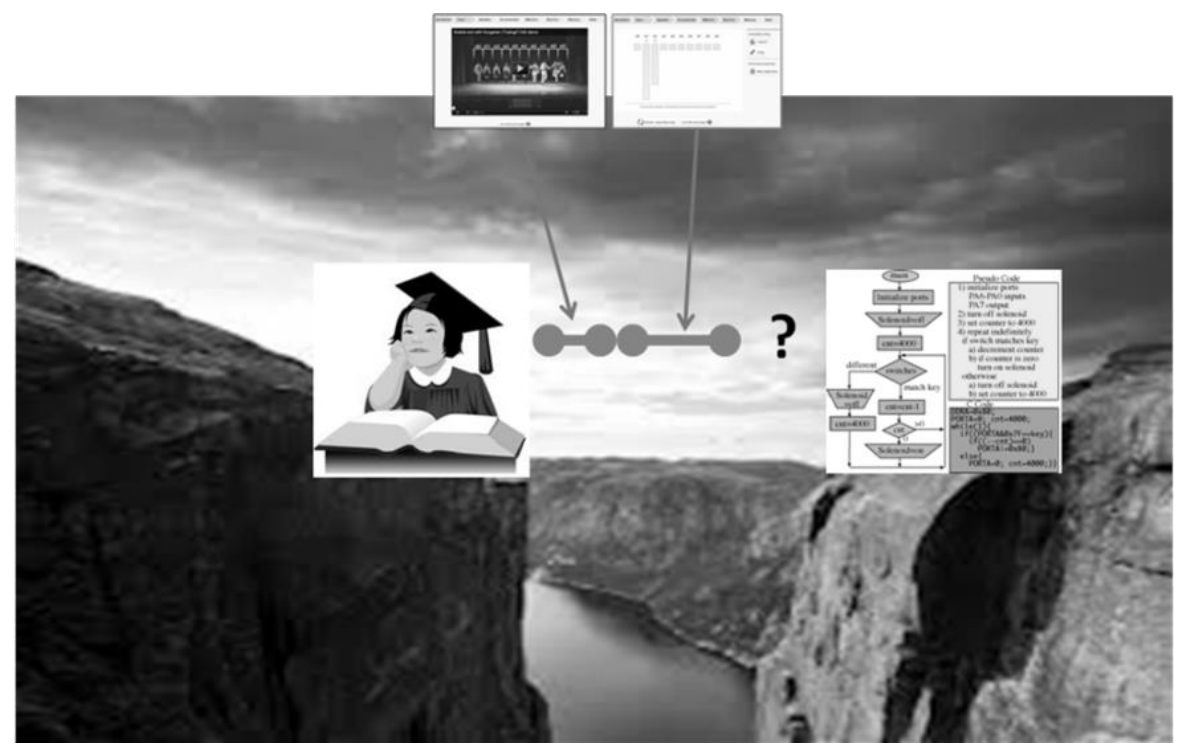

Fig. 3. Supporting students in understanding and coding the studied algorithms. 


\section{References}

Berlyne, D.E. (1960). Conflict, Arousal, and Curiosity. McGraw Hill Book Company, New York.

Day, H.I. (1971). The measurement of specific curiosity. In: Day, H.I., Berlyne, D.E., Hunt, D.E. (Eds.), Intrinsic Motivation: A New Direction in Education. Holt, Rinehart \& Winston, New York, 99-112

Deci, E.L., Ryan, R.M. (1985). Intrinsic motivation and self-determination in human behavior. Plenum, New York.

Dobbie, A.M.O. (1986). Comenius's Pampaedia or Universal Education. Buckland, Dover.

Eisenhower SCIMAST. (1997). How can research on the brain inform education.Classroom Compass, 3(2). 1-2, 10. http://www. sedl.org/pubs/classroom-compass/cc v3n2.pdf

Fair, E.M., Silvestri, L. (1992). Effects of rewards, competition and outcome on intrinsic motivation. Journal of Instructional Psychology, 19, 3-8.

Futschek, G. (2006). Algorithmic thinking: the key for understanding computer science. In: Mittermeir, R.T. (Ed.), Lecture Notes in Computer Science, 4226. Springer, Heidelberg, 159-168.

Futschek, G., Moschitz, J. (2010). Developing algorithmic thinking by inventing and playing algorithms. In: Proceedings of the 2010 Constructionist Approaches to Creative Learning, Thinking and Education: Lessons for the 21st Century (Constructionism 2010), Paris, 1-10.

http://publik.tuwien.ac.at/files/PubDat_187461.pdf

Gardner, H. (1993). Frames of mind (The tenth anniversary èd.). Basic Books, New York.

Gardner, H. (2000). Intelligence Reframed. Multiple Intelligences for the 21st Century. Basic Books, New York.

Garris, R., Ahlers, R., Driskell, J. (2002). Games, motivation and learning: a research and practice model. Simulation and Gaming, 33, 441-467.

Hung, D. (2003). Supporting current pedagogical approaches with neuroscience research. Journal of Interactive Learning Research, 14(2), 129-155.

Informatics Europe \& ACM Europe Working Group on Informatics Education (IE \& ACM) (2013). http://germany.acm.org/upload/pdf/ACMandIEreport.pdf

Informatics Europe (2013). http: / /www.informatics-europe.org/services/curriculum-award.html

Kashdan, T.B., Rose, P., Fincham, F.D. (2004). Curiosity and exploration: facilitating positive subjective experiences and personal growth opportunities. Journal of Personality Assessment, 82, 291-305.

Katai, Z., Juhasz, K., Adorjani, A.K. (2008). On the role of senses in education. Computers \& Education, 51(4), 1707-1717.

Katai, Z. (2011). Multi-sensory method for teaching-learning recursion. Computer Applications in Engineering Education, 19(2), 234-243.

Katai, Z., Toth, L. (2010). Technologically and artistically enhanced multi-sensory computer programming education. Teaching and Teacher Education. 26, 244-251.

Katai, Z. (2013). The challenge of promoting algorithmic thinking of both sciences and humanities oriented learners. Journal of Computer Assisted Learning. (Under review)

Katai, Z. (2014a). Intercultural computer science education. In: Proceedings of the 2014 Conference on Innovation \& Technology in Computer Science Education. ACM New York, NY, USA, 183-188. DOI: http://dx.doi.org/10.1145/2591708.2591744

Katai, Z. (2014b). The challenge of promoting algorithmic thinking of both sciences and humanities oriented learners. Journal of Computer Assisted Learning. DOI: http://dx. doi .org/10 .1111/jcal . 12070

Kavenaugh, J.F. (Ed.). (1991). The Language Continuum from Infancy to Literacy. York, Baltimore.

Keller, J.M. (1983). Motivational design of instruction. In: Reigeluth, C.M. (Ed.), Instructional-Design Theories and Models. Erlbaum, Hillsdale, NJ, 383-434.

Lepper, M.R., Malone, T.W. (1987). Intrinsic motivation and instructional effectiveness in computer-based education. In: Snow, R.E., Farr, M.J. (Eds.), Aptitude, Learning, and Instruction: III Conative and Affective Process Analysis. Erlbaum, Hillsdale, NJ, 255-296.

Lepper, M., Henderlong, J., Iyengar, S. (2005). Intrinsic and extrinsic motivational orientations in the classroom: age differences and academic correlates. Journal of Educational Psychology, 97, 184-196.

Martens, R.L., Gulikersw, J., Bastiaensw, T. (2004). The impact of intrinsic motivation on e-learning in authentic computer tasks. Journal of Computer Assisted Learning, 20, 368-376.

Nakamura, J., Csikszentmihalyi, M. (2002). The concept of flow. In: Snyder, C.R., Lopez, S.J. (Eds.), Handbook of Positive Psychology. Oxford University Press, Oxford, 89-105. 
Otta, M., Tavella, M. (2010). Motivation and engagement in computer-based learning tasks: investigating key contributing factors. World Journal on Educational Technology, 2(1) 1-15.

Palmer, D. (2005). A motivational view of constructivist-informed teaching. International Journal of Science Education, 27(15), 1853-1881.

Pedró, F. (2006). The New Millennium Learners: Challenging our Views on ICT and Learning. OECD-CERI. http: / / www. oecd.org.

Pintrich, P.R., Marx, R.W., Boyle, R.A. (1993). Beyond cold conceptual change: the role of motivational beliefs and classroom contextual factors in the process of conceptual change. Review of Educational Research, 63, 167-199.

Prensky, M. (2001). Digital Natives, Digital Immigrants. NCB University Press, 9(5), 113-118.

Prensky, M. (2007). Listen to the natives. Educational Leadership, 63(4), 8-13.

Ramadhan, H.A. (2000). Programming by discovery. Journal of Computer Assisted Learning, 16, 83-93.

Robertson, J., Howells, C. (2008). Computer game Design: opportunities for successful learning. Computers \& Education, 50(2), 559-578.

Shaywitz, S. (2003). Overcoming Dyslexia: A New and Complete Science-Based Program for Overcoming Reading Problems at any Level. Knopf, New York.

Spires, H.A., Lee, J.K., Turner, K.A. (2008) Having our say: Middle grade student perspectives on school, technologies, and academic engagement. Journal of Research on Technology in Education, 40(4), 497-515.

Staley, J.D. (2006). Imagining the Multisensory Classroom, Campus Technology, 6/6/2006. http://www.campustechnology.com/article.aspx?aid=40941

Stevens, J., Goldberg, D. (2001). For the Learners'Sake: A Practical Guide to Transform your Classroom and School. Zephyr Press, Tucson, AZ.

Turner, J., Meyer, D. (2004). A classroom perspective on the principle of moderate challenge in mathematics. The Journal of Educational Research, 97(6), 311-318.

Voto, D., Viñas, L.M., D’Auria, L. (2005). Multisensory interactive installation. In: Proceedings of the Sound and Music Computing '05, XV CIM. Salerno, Italy.

http://smcnetwork. org/files/proceedings/2005/MII20Paper\%20Salerno.pdf

Z. Katai (Zoltán Kátai) started his professional career (1992-) as an informatics teacher in secondary education. Nowadays (2003-) he is an associate professor (2014-) at Sapientia University (Mathematics and Informatics Department), Targu Mures, Romania. His research includes topics like dynamic programming, graph theory and informatics didactics, especially computer programming didactics.

L. Toth (László Tóth) obtained his BSc degree in informatics at Sapientia University (Targu Mures, Romania). He started his professional career (2008-) as web developer at www.bestjobs.ro, the biggest Romanian online recruiting website. Nowadays he is iOS developer at the same company. He is passionate in involving the online platforms and today's popular mobile devices like smart phones and tablets in teaching/learning processes.

A.K. Adorjani (Alpár Károly Adorjáni) obtained his BSc degree in software engineering at Sapientia University (Targu Mures, Romania). After one year MSc study in optimization models he graduated at Babes-Bolyai Univesity (Cluj, Romania), in 2009. Nowadays he works at a software company (InterSoft, Targu Mures) in developing 2D and 3D mesh generation applications. Beside informatics education, he is interested in programming $(\mathrm{c}++, \mathrm{mfc})$, geometry computations, $\mathrm{CAD}$ representation, etc. 


\section{Daugiasensorinis informatikos mokymas}

\section{Zoltan KATAI, Laszlo TOTH, Alpar Karoly ADORJANI}

Naujausioje jungtinès „Informatics Europe“ ir „ACM Europe“ darbo grupès ataskaitoje apie informatikos mokymą akcentuojama, kad: 1) algoritminis mąstymas yra svarbus gebejimas, kurị visi žmonès turi turèti; 2) informatikos konceptai, gebẻjimai ir įgūdžiai yra išmokomi ir turi būti ịtraukti i pradinio ir, svarbiausia, ị vidurinio ugdymo programas. Todèl „Informatics Europe“ organizuotas renginys „2013 Best Practices in Education Award“ buvo skirtas iniciatyvoms, skatinančioms informatikos mokymą pradinėse ir vidurinèse mokyklose. Šiame straipsnyje pristatomas vienas iš laimejusių projektų „Daugiasensorinis informatikos mokymas“. Siekdami pagerinti elementariu rūšiavimo ir rekursijos algoritmų mokymą ir mokymąsi, autoriai sukūrẻ efektyvius daugiasensorinius metodus ir programinius įrankius. Technologiškai praturtinta mokymosi aplinka taip pat turi potencialą skatinti tarpkultūrinį informatikos mokymą ir algoritminį mąstymą tiek tiksliujų, tiek humanitarinių mokslų mokiniams. 